\title{
Microbiological profile of Salpicão de Vinhais and Chouriça de Vinhais from raw materials to final products: Traditional dry sausages produced in the North of Portugal
}

\author{
V. Ferreira, J. Barbosa, J. Silva, P. Gibbs, T. Hogg, P. Teixeira* \\ Escola Superior de Biotecnologia, Universidade Católica Portuguesa, R. Dr. António Bernardino de Almeida, 4200-072 Porto, Portugal
}

Keywords:

Salpicão de Vinhais

Chouriça de Vinhais

Processing units

Microbiological profile

\begin{abstract}
A B S T R A C T
Salpicão de Vinhais and Chouriça de Vinhais are traditional dry-fermented meat sausages produced in the North of Portugal. The microbiological profile during production of both products was followed in three small processing units. Lactic acid bacteria were the most prevalent microorganisms, with enhanced growth during the smoking process and a consequent decrease of $\mathrm{pH}$.

This study demonstrated that when highly contaminated raw ingredients are used, pathogens might not be eliminated during processing (from seasoning until the end of smoking). Therefore, it is important to highlight that to produce safe Salpicão and Chouriça following traditional recipes and methodologies it is necessary to work under hygienic conditions using raw materials of good microbiological quality.

Industrial relevance: Preservation of pork meat in the form of semi-dry, fermented and smoked products having a long shelf-life, is an age-old artisanal process that is still practiced in many areas of the world. In many rural communities production has a significant impact on the local economy and food supply, but these products are now becoming increasingly popular in urban areas. In a more widespread distribution of such artisanal products, it is important that consumers are not exposed to undue risks of food-borne infections or intoxications. This study investigates the evolution of the microflora and microbiological safety during the production processes of two such traditional products in the North of Portugal, and during storage of the final products.
\end{abstract}

\section{Introduction}

Pork meat conserved in the form of fermented dry sausages is typical, and represents an important part of the traditional Portuguese diet. The production of these kinds of products has a significant impact on the economy of rural areas in the north of Portugal. Salpicão and Chouriça de Vinhais are dry-fermented sausages produced in Vinhais, a small region of Trás-os-Montes, where the natural conditions and specific climate allow a peculiar curing process and unique flavor. The essential ingredients of these products are raw pork meat from Bísaro, an autochthonous pig breed, salt, spices and regional wine. The process includes a first stage of seasoning for $48 \mathrm{~h}$ at $4{ }^{\circ} \mathrm{C}$; stuffing of the mixture in natural pork casings, and a final stage of curing by traditional smoking, at $20-30{ }^{\circ} \mathrm{C}$ for, approximately, 3 weeks for Chouriça and 4 weeks for Salpicão. In the production of Salpicão, only loin pork meat is used and stuffed into large intestine (cylindrical formed sausages, ca. $15-20 \mathrm{~cm}$ long), while in Chouriça, meat and pork fat are used, and stuffed into small intestine (horseshoe-shaped sausage, ca. 30-35 cm long).
Several authors have described the importance of the natural microflora during the fermentation process, namely lactic acid bacteria (LAB) and Micrococcaceae, responsible for inhibition of undesirable microbial growth (either by decreasing the $\mathrm{pH}$ or by production of anti-microbial compounds such as bacteriocins), and development of color and flavour (Bruna, Hierro, Ordóñez, \& de la Hoz, 1999; Nout \& Sarkar, 1999; Parente, Grieco, \& Crudele, 2001; Ammor \& Mayo, 2007; Benito, Martín, Pérez-Nevado, Ruiz-Moyano, \& Córdoba, 2007; Martín, Colín, Aranda, Benito, \& Córdoba, 2007). Together with the addition of salt and progressive decrease of water activity $\left(a_{\mathrm{w}}\right)$, fermentation is the only guarantee of safety in these products that do not receive any antimicrobial heat treatment before consumption.

Since these sausages are mainly produced by traditional customs at small processing units, conditions as time and temperature during the different processing stages are not controlled. Therefore, deviations may result in insufficient fermentation-drying processes, not assuring the absence of pathogens in the final products. The presence of foodborne pathogens in fermented sausages such as Listeria monocytogenes, Escherichia coli 0157:H7, Salmonella spp., Clostridium botulinum, and Staphylococcus aureus, has been reported (Siriken, Pamuk, Özakin, Gedikoglu, \& Eyigör, 2006; Ferreira et al., 2006; Ferreira, Barbosa, Silva, Felício, et al., 2007; Ferreira, Barbosa, Silva,

\footnotetext{
* Corresponding author. Tel.: +351 2255800 95; fax: +35122 5090351

E-mail address: pcteixeira@esb.ucp.pt (P. Teixeira).
} 
Vendeiro, et al., 2007; Talon et al., 2007; Keskinen, Todd, \& Ryser, 2008) and Moore (2004) reported various gastrointestinal disease outbreaks associated with the consumption of fermented meats.

The present work aimed to investigate the evolution of natural microflora during maturation of Salpicão and Chouriça de Vinhais produced at three different traditional plants and assess microbiological safety from the raw ingredients until final product.

\section{Materials and methods}

\section{Sampling}

Products from three traditional producers, located in the same area, were studied. In view of the fact that these are small industrial units, only one batch of each product is manufactured at each time. Therefore, for each producer, samples of one batch of Salpicão and one batch of Chouriça at different stages of production were collected: raw meat immediately after addition of spices and wine (T0); $48 \mathrm{~h}$ after seasoning at $4{ }^{\circ} \mathrm{C}(\mathrm{T} 1)$; after stuffing and before smoking (T2); in the middle period of smoking, corresponding to 11 and 15 days of smoking for Chouriça and Salpicão, respectively (T3); and final product (T4) (in a total of 22 days of smoking for Chouriça and 30 days for Salpicão). The processing stages and the respective sampling are described in Fig. 1. From each batch, two samples were analyzed. Samples were transported to the laboratory in portable, insulated cold-boxes and stored at $4{ }^{\circ} \mathrm{C}$ until they were analyzed.

\section{Microbiological analyses}

Twenty-five grams of each sample were added aseptically to $225 \mathrm{ml}$ of sterile Buffered Peptone Water (Merck, Darmstadt, Germany), and homogenized in a stomacher (Interscience, Saint Nom la Bretèche, France) for 2 min. Appropriate decimal dilutions were prepared in Ringer's solution (LabM, Bury, UK) for microbial enumeration: Total viable counts on Plate Count Agar (PCA, LabM) incubated at $30{ }^{\circ} \mathrm{C}$ for $72 \mathrm{~h}$, according to the Portuguese Standard NP 4405, lactic acid bacteria on de Man, Rogosa Sharpe Agar (MRS, LabM) and on M17 (Lab M) incubated at $30{ }^{\circ} \mathrm{C}$ for $72 \mathrm{~h}$, according to the International Standard ISO 15214 (F); Enterococcaceae on Bile Esculin Azide Agar (BEA, Biokar Diagnostics, Beauvais, France), incubated at $30{ }^{\circ} \mathrm{C}$ for $72 \mathrm{~h}$; Micrococcaceae on Mannitol Salt Agar (MSA, Biokar Diagnostics), incubated at $37^{\circ} \mathrm{C}$ for $48 \mathrm{~h}$; yeasts and moulds on RoseBengal Agar supplemented with $0.1 \mathrm{~g} \mathrm{~L}^{-1}$ of chloramphenicol (RBCA, Oxoid, Hampshire, UK), incubated at $25{ }^{\circ} \mathrm{C}$ for 5 days, according to the Portuguese Standard NP 3277-1; Enterobacteriaceae on Violet Red Bile

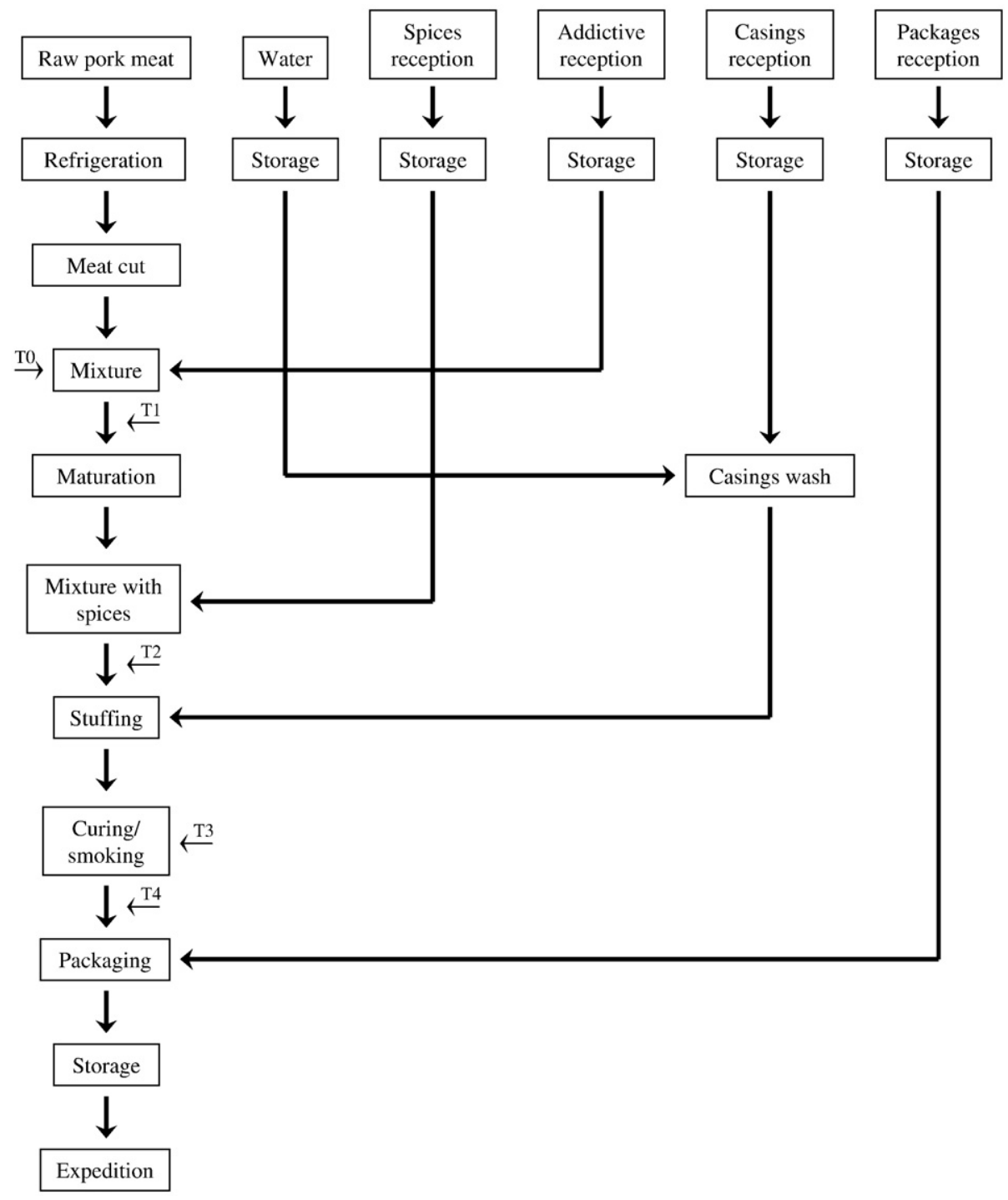

Fig. 1. Processing stages of "Salpicão" and "Chouriça" de Vinhais. 
Table 1

Microbiological profile of Salpicão and Chouriça during fermentation

\begin{tabular}{|c|c|c|c|c|c|c|c|c|c|}
\hline Product & Producer & $\begin{array}{l}\text { Time of } \\
\text { sampling }\end{array}$ & $\begin{array}{l}\text { Total viable counts } \\
\left(\log \mathrm{cfu} \mathrm{g}^{-1}\right)\end{array}$ & $\begin{array}{l}\text { Counts in MRS } \\
\left(\log \mathrm{cfu} \mathrm{g}^{-1}\right)\end{array}$ & $\begin{array}{l}\text { Counts in M17 } \\
\left(\log \mathrm{cfu} \mathrm{g}^{-1}\right)\end{array}$ & $\begin{array}{l}\text { Counts in MSA } \\
\left(\log \mathrm{cfu} \mathrm{g}^{-1}\right)\end{array}$ & $\begin{array}{l}\text { Enterococci } \\
\left(\log \mathrm{cfu} \mathrm{g}^{-1}\right)\end{array}$ & $\begin{array}{l}\text { Moulds } \\
\left(\log \mathrm{cfu} \mathrm{g}^{-1}\right)\end{array}$ & $\begin{array}{l}\text { Yeasts } \\
\left(\log \mathrm{cfu} \mathrm{g}^{-1}\right)\end{array}$ \\
\hline \multirow[t]{9}{*}{$\overline{\text { Salpicão }}$} & \multirow[t]{3}{*}{$\mathrm{A}$} & $\mathrm{T} 2$ & $5.7 \pm 0.01$ & $3.5 \pm 0.01$ & $4.2 \pm 0.00$ & $3.1 \pm 0.03$ & $3.2 \pm 0.16$ & 2.0 & 3.2 \\
\hline & & T3 & $9.0 \pm 0.19$ & $7.7 \pm 0.00$ & $7.2 \pm 0.00$ & $3.1 \pm 0.00$ & $3.1 \pm 0.05$ & 2.6 & 4.0 \\
\hline & & $\mathrm{T} 4$ & $9.0 \pm 0.03$ & $7.8 \pm 0.18$ & $7.7 \pm 0.17$ & $3.8 \pm 0.05$ & $7.1 \pm 0.01$ & 2.8 & 3.8 \\
\hline & \multirow[t]{3}{*}{ B } & $\mathrm{T} 2$ & $4.8 \pm 0.01$ & $3.7 \pm 0.04$ & $5.5 \pm 0.00$ & $3.6 \pm 0.05$ & $3.3 \pm 0.02$ & 4.0 & $<1.2$ \\
\hline & & T3 & $10.5 \pm 0.00$ & $9.8 \pm 0.06$ & $9.8 \pm 0.08$ & $3.7 \pm 0.03$ & $7.2 \pm 0.00$ & 4.0 & 4.6 \\
\hline & & $\mathrm{T} 4$ & $10.3 \pm 0.01$ & $9.0 \pm 0.01$ & $9.0 \pm 0.01$ & $3.7 \pm 0.01$ & $7.2 \pm 0.00$ & 5.1 & 6.1 \\
\hline & \multirow[t]{3}{*}{ C } & $\mathrm{T} 2$ & $8.0 \pm 0.01$ & $7.1 \pm 0.03$ & $7.2 \pm 0.01$ & $3.2 \pm 0.13$ & $5.3 \pm 0.08$ & $<1.0$ & 4.4 \\
\hline & & T3 & $8.7 \pm 0.02$ & $7.0 \pm 0.00$ & $7.1 \pm 0.14$ & $3.8 \pm 0.02$ & $6.0 \pm 0.04$ & $<1.2$ & 4.3 \\
\hline & & $\mathrm{T} 4$ & $7.6 \pm 0.31$ & $6.0 \pm 0.02$ & $7.9 \pm 0.01$ & $3.7 \pm 0.24$ & $5.5 \pm 0.06$ & 0.8 & 4.3 \\
\hline \multirow[t]{9}{*}{ Chouriça } & \multirow[t]{3}{*}{ A } & $\mathrm{T} 2$ & $10.3 \pm 0.01$ & $5.3 \pm 0.01$ & $5.3 \pm 0.07$ & $3.4 \pm 0.06$ & $4.9 \pm 0.01$ & 2.4 & 3.5 \\
\hline & & T3 & $9.9 \pm 0.02$ & $8.9 \pm 0.02$ & $8.5 \pm 0.04$ & $4.1 \pm 0.03$ & $6.9 \pm 0.01$ & 3.7 & 3.5 \\
\hline & & $\mathrm{T} 4$ & $9.4 \pm 0.40$ & $8.8 \pm 0.11$ & $8.2 \pm 0.08$ & $4.2 \pm 0.55$ & $7.0 \pm 0.06$ & 4.1 & 3.9 \\
\hline & \multirow[t]{3}{*}{ B } & $\mathrm{T} 2$ & $10.3 \pm 0.04$ & $7.8 \pm 0.04$ & $7.8 \pm 0.04$ & $4.9 \pm 0.01$ & $3.5 \pm 0.07$ & $<1.0$ & 3.4 \\
\hline & & T3 & $8.1 \pm 0.01$ & $9.7 \pm 0.14$ & $9.8 \pm 0.05$ & $3.6 \pm 0.01$ & $7.2 \pm 0.00$ & 4.0 & 2.2 \\
\hline & & $\mathrm{T} 4$ & $9.5 \pm 0.11$ & $8.4 \pm 0.00$ & $8.5 \pm 0.01$ & $3.8 \pm 0.01$ & $>7.2$ & 3.7 & 4.7 \\
\hline & \multirow[t]{3}{*}{ C } & $\mathrm{T} 2$ & $4.0 \pm 0.33$ & $6.2 \pm 0.06$ & $5.6 \pm 0.11$ & $3.3 \pm 0.07$ & $4.2 \pm 0.07$ & $<1.0$ & $<1.0$ \\
\hline & & T3 & $8.0 \pm 0.05$ & $7.4 \pm 0.01$ & $7.1 \pm 0.05$ & $3.5 \pm 0.35$ & $5.7 \pm 0.04$ & $<1.0$ & 4.2 \\
\hline & & $\mathrm{T} 4$ & $8.0 \pm 0.65$ & $7.0 \pm 0.64$ & $7.7 \pm 0.17$ & $3.7 \pm 0.15$ & $5.3 \pm 0.35$ & $<1.0$ & 3.3 \\
\hline
\end{tabular}

Legend: T2 - after stuffing and before smoking; T3 - middle of smoking process (after 11 and 15 days of smoking for Chouriça and Salpicão, respectively); T4 - final product.

with Lactose (VRBL, Biokar Diagnostics), incubated at $37{ }^{\circ} \mathrm{C}$ for $24 \mathrm{~h}$, according to the Portuguese Standard NP 4137; E. coli on Tryptonebile-glucuronide (TBX, BioRad, Hercules, CA, USA), incubated at $44{ }^{\circ} \mathrm{C}$ for $24 \mathrm{~h}$ according to the French Standard NF V 08-053; coagulasepositive staphylococci on Baird-Parker RPF-agar (bioMérieux, Marcy l'Etoile, France), incubated at $37{ }^{\circ} \mathrm{C}$ for $48 \mathrm{~h}$, according to the Portuguese standard NP 4400-2; and sulphite reducing Clostridium spores according to the Portuguese Standard NP 2262.

Salmonella spp. was detected by the VIDAS method, an enzymelinked fluorescent immunoassay performed in the automated VIDAS instrument, using antibody specific for Salmonella spp. Confirmation of positive results was performed using as enrichment broths RappaportVassiliadis (bioMérieux) and Muller-Kauffmann Tetrathionate (bioMér- ieux), according to the standard techniques described in the International Standard ISO 6579. L. monocytogenes was also detected by VIDAS method, using antibody specific for L. monocytogenes, and enumerated by both direct count technique, using Palcam medium (Merck) and the most probable number (MPN) technique, using culture medium DemiFraser broth (Merck), Fraser broth (Merck) and Palcam medium (MercK), according to ISO 11290-1.

\section{$\mathrm{pH}$ determination}

The $\mathrm{pH}$ was monitored during the different processing stages ( $\mathrm{T} 0$, T1, T2, T3 and T4). The determination of the $\mathrm{pH}$ was performed directly using a Crison MicropH 2002 pH-meter (Crison, Barcelona,

Table 2

Microbiological and pH profile of Salpicão and Chouriça from raw materials to final products: commonly controlled microbial safety parameters

\begin{tabular}{|c|c|c|c|c|c|c|c|}
\hline Product & Producer & Time of sampling & $\begin{array}{l}\text { Enterobacteriaceae } \\
\left(\log \mathrm{cfu} \mathrm{g}^{-1}\right)\end{array}$ & $\begin{array}{l}\text { S. aureus } \\
\left(\log \mathrm{cfu} \mathrm{g}^{-1}\right)\end{array}$ & $\begin{array}{l}\text { E. coli } \\
\left(\log \mathrm{cfu} \mathrm{g}^{-1}\right)\end{array}$ & S. R. C. spores & $\mathrm{pH}$ \\
\hline \multirow[t]{15}{*}{ Salpicão } & \multirow[t]{5}{*}{ A } & T0 & $6.7 \pm 0.04$ & 2.9 & 3.9 & $(-) 1 \mathrm{~g}$ & 5.6 \\
\hline & & $\mathrm{T} 1$ & $6.1 \pm 0.03$ & 2.5 & 4.1 & $(-) 1 \mathrm{~g}$ & 5.7 \\
\hline & & $\mathrm{T} 2$ & $5.2 \pm 0.02$ & $<1.0$ & 2.9 & $(-) 1 \mathrm{~g}$ & 5.8 \\
\hline & & $\mathrm{T} 3$ & $5.0 \pm 0.03$ & $<1.0$ & 4.0 & $(-) 1 \mathrm{~g}$ & 5.3 \\
\hline & & $\mathrm{T} 4$ & $6.6 \pm 0.85$ & 3.5 & 4.6 & $(-) 1 \mathrm{~g}$ & 5.3 \\
\hline & \multirow[t]{5}{*}{ B } & T0 & $5.5 \pm 0.07$ & $<1.0$ & 5.4 & $(-) 1 \mathrm{~g}$ & 5.4 \\
\hline & & $\mathrm{T} 1$ & $6.8 \pm 0.02$ & $<1.0$ & 5.3 & $(-) 1 \mathrm{~g}$ & 5.5 \\
\hline & & $\mathrm{T} 2$ & $3.5 \pm 0.01$ & $<1.0$ & 3.3 & $(+) 0.1 \mathrm{~g} /(-) 0.01 \mathrm{~g}$ & 5.4 \\
\hline & & T3 & $5.1 \pm 0.01$ & $<1.0$ & 4.1 & $(-) 1 \mathrm{~g}$ & 5.2 \\
\hline & & $\mathrm{T} 4$ & $4.1 \pm 0.01$ & $<1.0$ & 3.1 & $(-) 1 \mathrm{~g}$ & 5.3 \\
\hline & \multirow[t]{5}{*}{$\mathrm{C}$} & T0 & $<1.0$ & $<1.0$ & $<1.0$ & $(+) 1 \mathrm{~g} /(-) 0.1 \mathrm{~g}$ & 5.6 \\
\hline & & $\mathrm{T} 1$ & $<1.0$ & $<1.0$ & $<1.0$ & $(-) 1 \mathrm{~g}$ & 5.5 \\
\hline & & $\mathrm{T} 2$ & $<1.0$ & $<1.0$ & $<1.0$ & $(+) 1 \mathrm{~g} /(-) 0.1 \mathrm{~g}$ & 5.4 \\
\hline & & T3 & $<1.0$ & $<1.0$ & $<1.0$ & $(+) 0.1 \mathrm{~g} /(-) 0.01 \mathrm{~g}$ & 5.4 \\
\hline & & $\mathrm{T} 4$ & $<1.0$ & $<1.0$ & $<1.0$ & $(+) 1 \mathrm{~g} /(-) 0.1 \mathrm{~g}$ & 5.4 \\
\hline \multirow[t]{15}{*}{ Chouriça } & \multirow[t]{5}{*}{ A } & T0 & $4.5 \pm 0.06$ & $<1.0$ & 3.8 & $(-) 1 \mathrm{~g}$ & 5.6 \\
\hline & & $\mathrm{T} 1$ & $5.4 \pm 0.08$ & 3.9 & 4.2 & $(-) 1 \mathrm{~g}$ & 5.7 \\
\hline & & $\mathrm{T} 2$ & $4.7 \pm 0.03$ & $<1.0$ & 3.6 & $(-) 1 \mathrm{~g}$ & 5.7 \\
\hline & & T3 & $5.6 \pm 0.06$ & $<1.0$ & 4.3 & $(+) 1 \mathrm{~g} /(-) 0.1 \mathrm{~g}$ & 5.4 \\
\hline & & $\mathrm{T} 4$ & $6.0 \pm 0.69$ & $<1.0$ & 5.2 & $(-) 1 \mathrm{~g}$ & 5.4 \\
\hline & \multirow[t]{5}{*}{ B } & T0 & $7.5 \pm 0.00$ & $<1.0$ & $>6.5$ & $(-) 1 \mathrm{~g}$ & 5.5 \\
\hline & & $\mathrm{T} 1$ & $7.5 \pm 0.00$ & $<1.0$ & $>6.5$ & $(-) 1 \mathrm{~g}$ & 5.6 \\
\hline & & $\mathrm{T} 2$ & $6.0 \pm 0.01$ & $<1.0$ & 5.9 & $(-) 1 \mathrm{~g}$ & 5.6 \\
\hline & & T3 & $7.0 \pm 0.04$ & $<1.0$ & 6.3 & $(-) 1 \mathrm{~g}$ & 5.3 \\
\hline & & $\mathrm{T} 4$ & $6.0 \pm 0.01$ & $<1.0$ & 5.5 & $(+) 0.1 \mathrm{~g} /(-) 0.01 \mathrm{~g}$ & 5.3 \\
\hline & \multirow[t]{5}{*}{$\mathrm{C}$} & T0 & $<1.0$ & $<1.0$ & $<1.0$ & $(-) 1 \mathrm{~g}$ & 5.7 \\
\hline & & $\mathrm{T} 1$ & $<1.0$ & $<1.0$ & $<1.0$ & $(-) 1 \mathrm{~g}$ & 5.6 \\
\hline & & $\mathrm{T} 2$ & $<1.0$ & $<1.0$ & $<1.0$ & $(-) 1 \mathrm{~g}$ & 5.5 \\
\hline & & T3 & $<1.0$ & $<1.0$ & $<1.0$ & $(-) 1 \mathrm{~g}$ & 5.4 \\
\hline & & $\mathrm{T} 4$ & $<1.0$ & $<1.0$ & $<1.0$ & $(-) 1 \mathrm{~g}$ & 5.4 \\
\hline
\end{tabular}

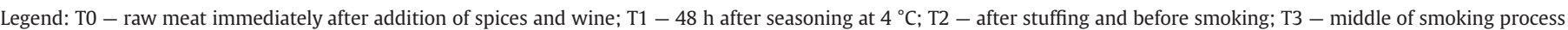
(after 11 and 15 days of smoking for Chouriça and Salpicão, respectively); T4 - final product. 
Spain), equipped with an InLab 427 puncture electrode (Mettler Toledo, Columbus, $\mathrm{OH}$ ), inserted into each sample.

\section{Results and discussiion}

Table 1 reports the results for microbiological evolution during maturation of Salpicão and Chouriça de Vinhais (sampling points T2 to T4). For each microorganism analyzed similar patterns were observed for both Salpicão and Chouriça. In fact at each processing plant both sausages were produced at the same time and under the same conditions using some raw materials in common. Some of these were even used by the different producers.

Lactic acid bacteria present in low numbers at the beginning of fermentation increased during the process and became the predominant flora in final products, in agreement with results previously reported for similar fermented sausages (Papamanoli, Kotzekidou, \& Tzanetakis, 2002; Caponio, Summo, Minervini, \& Gobbetti, 2006; Ferreira et al., 2006; Ferreira, Barbosa, Silva, Vendeiro, et al., 2007). A study performed by. Kozačinski et al. (2008) on traditional fermented sausages from countries of west and south-east Europe, revealed numbers of $\mathrm{LAB}$ in pork meat ranged from 4 to $5 \log \mathrm{cfu} \mathrm{g}^{-1}$. These microorganisms ferment sugars that result in production of acids and a decrease of $\mathrm{pH}$, which are responsible for the sensory quality and correct texture of the final products, as well as its preservation (Fernández, Santos, Jaime, \& Rovira, 1997; Sanz, Flores, Toldra, \& Feria, 1997; Castaño, Fontán, Fresno, Tornadijo, \& Carballo, 2002; Cenci-Goga, Ranucci, Miraglia, \& Cioffi, 2008). A good indicator of the development of this microflora was the $\mathrm{pH}$ values observed in the final products, ranging from 5.3-5.4. During the processes investigated, enterococci grew to values higher than $5 \log \mathrm{cfu} \mathrm{g}^{-1}$. An exception was Salpicão from producer $C$ as these organisms were already present in high levels at the beginning of the fermentation. The role of enterococci in fermented products has been discussed. If they have beneficial effects as antimicrobial agents and improve sausage sensorial quality (Sarantinopoulos et al., 2001), they could also compromise their safety as some strains have been described as opportunistic pathogens (Franz, Holzapfel, \& Stiles, 1999; Eaton \& Gasson, 2001).

The levels of Micrococcaceae were around $3 \log \mathrm{cfu} \mathrm{g}^{-1}$ in the first stage of fermentation and their development was not significantly enhanced during the smoking process. This fact may be related to some inhibition caused by the decrease in $\mathrm{pH}$ as described by other authors (Sanz et al., 1997; Bruna et al., 1999; Papamanoli et al., 2002). Beneficial effects such as production of aromatic compounds and reduction of nitrates to nitrites, inhibiting Clostridium spp. growth, have been attributed to Micrococcaceae (Montel, Masson, \& Talon, 1998; Bruna et al., 1999; García-Varona, Santos, Jaime, \& Rovira, 2000).

Moulds and yeasts were present in both products for all producers, with a slight increase during the fermentation process, except for producer C, where moulds were at low levels in Salpicão and absent in Chouriça. Their contribution to the development of sensorial qualities of dry fermented sausages has been described previously (Geisen, Lücke, \& Kröckel, 1992; Encinas, López-Díaz, Garcia-López, Otero, \& Moreno, 2000).

Salmonella spp. was not detected in any sample. Mayrhofer, Paulsen, Smulders, \& Hilbert, 2004) has previously reported that the prevalence of Salmonella spp. was low in pork meat. Ferreira, Barbosa, Silva, Felício, et al. (2007) and Ferreira, Barbosa, Silva, Vendeiro, et al. (2007) only detected Salmonella spp. in two out of the 38 lots of Alheira (traditional Portuguese sausage produced in the North of Portugal) investigated.

L. monocytogenes was not detected by Vidas or direct count techniques in any sample. Although, it was detected by the most probable number technique in samples taken at T1 $\left(4.9 \mathrm{MPN} \mathrm{g}^{-1}\right)$ and T2 $(0.2$ MPN $\mathrm{g}^{-1}$ ) from producer $\mathrm{B}$, this pathogen was absent in the final product. $L$. monocytogenes is frequently found in raw materials and food processing environments therefore being frequently isolated during the early stages of sausages fermentations. The reduction of this contaminant during the smoking process has been reported in other studies (Thévenot, Delignette-Muller, Christieans, \& VernozyRozand, 2005; Kozačinski et al., 2008). This could be the result of a set of hurdles such as low $\mathrm{pH}$, low $a_{\mathrm{w}}$, high salt concentration, competition with other organisms or the presence of antilisterial compounds.

Results concerning the other pathogens or indicator organisms are presented in Table 2. According to the Food Safety Authority of Ireland Guidelines (2001), both Salpicão and Chouriça from producers A and B would be classified as Unsatisfactory as Enterobacteriaceae and E. coli counts were higher than $\log 4 \mathrm{cfu} \mathrm{g}^{-1}$ and $\log 2 \mathrm{cfu} \mathrm{g}^{-1}$, respectively. These organisms were present at high levels in all processing stages. For producer $\mathrm{B}$ a slight decrease was observed between middle of smoking and final product, for both Salpicão and Chouriça. On the contrary, for producer A, an increase of cellular counts occurred. The high levels observed in final products can be related to the availability of nutrients and with the values of $\mathrm{pH}$ and $a_{\mathrm{w}}$ being still compatible with the growth of these organisms (Leyer, Wang, \& Johnson, 1995; Ganzle, Hertel, \& Hammes, 1999) and indicates that they are not eliminated at the processing conditions. On the basis of these results it can be inferred that these products were produced under deficient hygienic conditions and/ or using raw material of poor microbiological quality.

S. aureus was present only in samples from producer A at levels not considered hazardous (lower than $4 \log \mathrm{cfu}^{-1}$ ) but still unsatisfactory (higher than $2 \log \mathrm{cfu} \mathrm{g}^{-1}$ ). In Chouriça, S. aureus was only found $48 \mathrm{~h}$ after seasoning; in Salpicão, it also was present $48 \mathrm{~h}$ after seasoning and in the final product.

Sulphite reducing Clostridium spores were found in Salpicão from producer $\mathrm{C}$, from the beginning of seasoning until the final product. For the other two producers, only producer B showed contamination of the final product.

Even with lactic acid bacteria being the most prevalent microorganisms, with enhanced growth during the smoking process resulting in a decrease of $\mathrm{pH}$, the microbiological safety of Chouriça and Salpicão cannot be assured if highly contaminated raw materials are used. Therefore, it is important to highlight, taking producer $\mathrm{C}$ as an example, that it is possible to produce safe Salpicão and Chouriça following traditional recipes, working under hygienic conditions and using raw materials of good microbiological quality.

\section{Acknowledgements}

This research was supported by project POCTI/AGG/39587/2001, Fundação para a Ciência e Tecnologia (FCT)/Fundo Europeu de Desenvolvimento Regional (FEDER) and European Economic Community IP016264-2 project, “ TRUE FOOD, Traditional United Europe Food. Financial support for author V. Ferreira was provided by PhD fellowship, SFRH/BD/24240/2005 (FCT).

\section{References}

Ammor, M. S., \& Mayo, B. (2007). Selection criteria for lactic acid bacteria to be used as functional cultures in dry sausage production: An update. Meat Science, 76, 138-146. Benito, M. J., Martín, A., Pérez-Nevado, F., Ruiz-Moyano, S., \& Córdoba, M. G. (2007). Characterization and selection of autochthonous lactic acid bacteria isolated from traditional Iberian dry-fermented salchichón and chorizo sausages. Journal of Food Science, 72, 193-201.

Bruna, M. J., Hierro, E. M., Ordóñez, J. A., \& de la Hoz, L. (1999). Changes in the components of dry-fermented sausages during ripening. Critical reviews in Food Science and Nutrition, 39, 329-367.

Caponio, F., Summo, C., Minervini, F., \& Gobbetti, M. (2006). Characterisation and quality assessment of ripened sausages in relation to the origin of raw material used. European. Food Research Technology, 222, 376-379.

Castaño, A., Fontán, M. C. G., Fresno, J. M., Tornadijo, M. E., \& Carballo, J. (2002). Survival of Enterobacteriaceae during processing of Chorizo de cebolla, a Spanish fermented sausage. Food Control, 13, 107-115.

Cenci-Goga, B. T., Ranucci, D., Miraglia, D., \& Cioffi, A. (2008). Use of starter cultures of dairy origin in the production of Salame nostrano, an Italian dry-cured sausage. Meat Science, 78, 381-390. 
Eaton, T. J., \& Gasson, M. J. (2001). Molecular screening of Enterococcus virulence determinants and potential for genetic exchange between food and medical isolates. Applied Environmental Microbiology, 67, 1628-1635.

Encinas, J. P., López-Díaz, T. M., Garcia-López, M. L., Otero, A., \& Moreno, B. (2000). Yeast populations on Spanish fermented sausages. Meat Science, 54, 203-208.

Fernández, G., Santos, E. M., Jaime, I., \& Rovira, J. (1997). Use of starter cultures in dry fermented sausage (Chorizo) and their influence on the sensory properties. Food Science and Technology International, 3, 31-42.

Ferreira, V., Barbosa, J., Silva, J., Felício, M. T., Mena, C., Hogg, T., et al. (2007) Characterisation of alheiras, traditional sausages produced in the North of Portugal with respect to their microbiological safety. Food Control, 18, 436-440.

Ferreira, V., Barbosa, J., Silva, J., Vendeiro, S., Mota, A., Silva, F., et al. (2007). Chemical and microbiological characterisation of "Salpicão de Vinhais" and "Chouriça de Vinhais": Traditional dry sausages produced in the North of Portugal. Food Microbiology, 24, 618-623.

Ferreira, V., Barbosa, J., Vendeiro, S., Mota, A., Silva, F., Monteiro, M. J., et al. (2006). Chemical and microbiological characterization of alheira: A typical Portuguese fermented sausage with particular reference to factors relating to food safety. Meat Science, 73, 570-575.

Food Safety Authority of Ireland (2001). Guidelines for the interpretation of results of microbiological analysis of some ready to eat foods sampled at the point of sale. Guidance Note No 3. Available on /http://www.fsai.ie/publications/index.aspS

Franz, C. M. A. P., Holzapfel, W. H., \& Stiles, M. E. (1999). Enterococci at the crossroads of food safety? International Journal of Food Microbiology, 47, 1-24.

Ganzle, M. G., Hertel, C., \& Hammes, W. P. (1999). Resistance of Escherichia coli and Salmonella against nisin and curvacin A. International Journal of Food Microbiology, 48, 37-50.

García-Varona, M., Santos, E. M., Jaime, I., \& Rovira, J. (2000). Characterisation of Micrococcaceae isolated from different varieties of chorizo. International Journal of Food Microbiology, 54, 189-195.

Geisen, R., Lücke, F. K., \& Kröckel, L. (1992). Starter and protective cultures for meat and meat products. Fleischwirtsch, 72, 894.

Keskinen, L. A., Todd, E. C. D., \& Ryser, E. T. (2008). Impact of bacterial stress and biofilmforming ability on transfer of surface-dried Listeria monocytogenes during slicing of delicatessen meats. International Journal of Food Microbiology, 127, 298-304.

Kozačinski, L., Drosinos, E., Čaklovica, F., Cocolin, L., Gasparik-Reichardt, J., \& Vesković, S. (2008). Investigation of microbial association of traditionally fermented sausages. Food Technology and Biotechnology, 46(1), 93-106.
Leyer, G. J., Wang, L. L., \& Johnson, E. A. (1995). Acid adaptation of Escherichia coli 0157:H7 increases survival in acidic foods. Applied Environmental Microbiology, 61, 3752-3755.

Martín, A., Colín, B., Aranda, E., Benito, M. J., \& Córdoba, M. G. (2007). Characterization of Micrococcaceae isolated from Iberian dry-cured sausages. Meat Science, 75, 696-708.

Mayrhofer, S., Paulsen, P., Smulders, F. J. M. \& Hilbert, F. (2004). Antimicrobial resistance profile of five major food-borne pathogens isolated from beef, pork and poultry. International Journal of Food Microbiology, 97, 23-29.

Montel, M. C., Masson, F., \& Talon, R. (1998). Bacterial role in flavor development. Meat Science, 49, S111-S123.

Moore, J. E. (2004). Gastrointestinal outbreaks associated with fermented meats. Meat Science, 67, 565-568.

Nout, M. J. R., \& Sarkar, P. K. (1999). Lactic acid food fermentation in tropical climates. Antonie van Leeuwenhoek, 76, 395-4001.

Papamanoli, E., Kotzekidou, P., \& Tzanetakis, N. (2002). Characterization of Micrococcaceae isolated from dry fermented sausage. Food Microbiology, 19, 441-449.

Parente, E., Grieco, S., \& Crudele, M. A. (2001). Phenotypic diversity of lactic acid bacteria isolated from fermented sausages produced in Basilicata (Southern Italy). Journal Applied Microbiology, 90, 943-952.

Sanz, Y., Flores, J., Toldra, F., \& Feria, A. (1997). Effect of pre-ripening on microbial and chemical changes in dry fermented sausages. Food Microbiology, 14, 575-582.

Sarantinopoulos, P., Andrighetto, C., Georgalaki, M. D., Rea, M. C., Lombardi, A., \& Cogan, T. M. (2001). Biochemical properties of Enterococci relevant to their technological performance. International Dairy Journal, 11, 621-647.

Siriken, B. S., Pamuk, S., Özakin, C., Gedikoglu, S., \& Eyigör, M. (2006). A note on the incidences of Salmonella spp., Listeria spp. and Escherichia coli 0157:H7 serotypes in Turkish sausages (Soudjouck). Meat Science, 72, 177-181.

Talon, R., Lebert, I., Lebert, A., Leroy, S., Garriga, M., Aymerich, T., et al. (2007). Traditional dry fermented sausages produced in small-scale processing units in Mediterranean countries and Slovakia. 1: Microbial ecosystems of processing environments. Meat Science, $77,570-579$.

Thévenot, D., Delignette-Muller, M. L., Christieans, S., \& Vernozy-Rozand, C. (2005). Prevalence of Listeria monocytogenes in 13 dried sausage processing plants and their products. Food Microbiology, 102, 85-94. 